\title{
Türkiye ve Singapur Okul Öncesi Eğitim Programlarının Matematik İçeriklerinin Karşılaştırılması
}

\author{
Comparison of the Mathematics Content of Curriculum for \\ Kindergartens in Turkey and Singapore
}

\author{
Ali Bozkurt ${ }^{1}$, Yakup Şapul ${ }^{2}$, Tuğba Han Şimşekler Dizman ${ }^{3}$
}

\begin{abstract}
Makale Geçmişi
Gelis : : 5 Mart 2020

Düzeltme : 26 Mayıs 2020

Kabul : 16 Haziran 2020
\end{abstract}

Makale Türü

Arasturma Makalesi

Article History

Received : 5 March 2020

Revised : 26 May 2020

Accepted : 16 June 2020

\section{Article Type}

Research Article

\begin{abstract}
Öz: Bu çalışmada, Türkiye ve Singapur Okul Öncesi Eğitim Programlarının matematik içeriklerinin (kazanım ve göstergeler) benzerlik ve farklılıkları ortaya konulmaya çalışılmıştır. Araştırma nitel olarak desenlenmiștir. Veri toplama tekniği olarak doküman incelemesi kullanılmıştır. Doküman olarak yürürlükte olan Türkiye ve Singapur Okul Öncesi Eğitim Programlarının matematik içerikleri kullanılmıştır. Verilerin analizinde içerik analiz yöntemi kullanılmıştır. Araştırmadan elde edilen bulgulara göre; Türkiye ve Singapur Okul Öncesi Eğitim Programlarının amaçlar bakımından benzer özellikler gösterdikleri; ancak Türkiye Okul Öncesi Eğitim Programının (TOEP) gelişimsel alanlar üzerine kurulduğu, Singapur Okul Öncesi Eğitim Programının (SOEP) ise öğrenme alanları üzerine kurulduğu görülmüştür. Ayrıca TOEP’te matematik içeriği kazanım ve göstergeler düzeyinde özet olarak verilmişken SOEP’te öğrenme alanlarına göre 6 farklı kılavuz hazırlanmıştır. Bu kılavuzlardan 64 sayfadan oluşan aritmetik kılavuzunda matematik öğretimine yönelik öğrenme hedefleri, stratejiler, öğrenme ortamını düzenleme ile gözlem ve değerlendirme bölümleri detaylandırılmıştır. İki programda da çocuklara sayı öncesi kavramlar, sayı hissi, şekil ve temel mekânsal kavramları geliştirmelerine yönelik kazanım ve göstergelere yer verilmiştir.
\end{abstract}

Anahtar Kelimeler: Matematik eğitimi, Öğrenme alanı, Türkiye okul öncesi eğitim programı, Singapur okul öncesi eğitim programı

\begin{abstract}
In this study, the mathematical content (learning outcomes and indicators) of Turkey and Singapore preschool education curriculum have tried to reveal similarities and differences. Document analysis was used as a method in the research. To collect the data, mathematical learning goal of curriculum for kindergartens in Turkey and Singapore were examined. Content analysis method was used in data analysis. From the findings obtained in that studying when compared with the general structure of preschool education in Turkey and Singapore, they have similarities in terms of objectives; however Turkish Ministry of National Educational Preschool Education Curriculum (TPEC) is built on development areas and Curriculum for Kindergartens in Singapore (CKS) is based on learning goals. In addition, mathematics content in TPEC was summarized at the level of learning indicators, while 6 different guidelines were prepared according to learning goals in CKS. The 64-page arithmetic guide of that guides includes detailed learning goals, learning strategies, organizing the learning environment, observation and assessment for mathematics teaching. Both programs provided opportunities for children to develop essential pre-number, number sense, shape and simple spatial concepts.
\end{abstract}

Keywords: Mathematics education, Learning goals, Turkish Ministry of National Educational Preschool Education Curriculum, Curriculum for Kindergartens in Singapore

\footnotetext{
Başlıca Yazar: Ali BOZKURT

*Bu çalışma ikinci yazarın Gaziantep Üniversitesi Eğitim Bilimleri Enstitüsü’nde tamamladığı yüksek lisans tezinden türetilmiştir.

1 Gaziantep Üniversitesi., Gaziantep Eğitim Fakültesi., Matematik ve Fen Bil. Eğitimi Bölümü, alibozkurt@gantep.edu.tr, ORCID: https://orcid.org/0000-0002-0176-4497

2 Gaziantep Üniversitesi, Eğitim Bilimleri Enstitüsü, İlköğretim Matematik Eğitimi Anabilim Dalı, yakupspl@gmail.com, ORCID: https://orcid.org/0000-0002-1779-0630

3 Gaziantep Üniversitesi, Gaziantep Eğitim Fakültesi, Matematik ve Fen Bil. Eğitimi Bölümü, alibozkurt@gantep.edu.tr ORCID: https://orcid.org/0000-0003-4709-6102
} 


\section{SUMMARY}

\section{Introduction}

This study aims to compare the contents of the pre-school curriculum's mathematics content of Turkey and Singapore since Singapore is one of the most successful countries in international student assessment tests. There are very few comparative educational studies examining the preschool education curriculum in terms of mathematics education. For this reason, the study is expected to contribute to the literature.

\section{Method}

In this study, document analysis method was used. In this context, the mathematical contents of Turkish Ministry of National Educational Preschool Education Curriculum (TPEC) and Curriculum for Kindergartens in Singapore (CKS) were analyzed. To collect the data, mathematical education of Turkey and Singapore preschool education programs were examined. Content analysis method was used in data analysis. In this context, while searching for answers to the research question the learning outcomes in the programs were primarily classified under four learning domains. Three of these learning areas are the learning goals, which are the main topics of mathematics learning outcomes mentioned in CKS. The fourth learning area was formed because learning outcomes of the measurement skill in TPEC was excluded from these three learning areas.

\section{Results}

There are three common learning goals in both programs: (a) recognize and use simple relationships and patterns, (b) use numbers in daily experiences, and (c) recognize and use basic shapes and simple spatial concepts in daily experiences. Unlike CKS, TPEC contains the learning goal of "recognize and use measurement units." There are five common learning goals in both TPEC and CKS under the learning area of "knowing simple relationships and patterns." Also, compared to CKS, TPEC contains two additional learning goals under the same learning area. Under the learning area of "counting and number sense in everyday life," TPEC contains three learning goals while CKS contains nine learning goals. Under the learning area of "identifying and naming basic shapes," CKS contains two learning goals. In TPEC, on the other hand, this learning goal includes the ability to define the properties of geometric shapes and to show objects that resemble geometric shapes.

Note that, the lack of related learning goal in a country's curriculum while comparing two country does not mean that the skill that this achievement expects is not in that country's program. For example, the learning goal of "explains time related concepts" which existed in TPEC, but not existed in CKS, is given in other learning goal that is "putting things in an order according to size 
or length and sequence events" as a learning indicator. There is 1 learning goal existed in TPEC in the field of "learning and using measurement units", but not existed in CKS

\section{Conclusion and Discussion}

The learning goal of "sorting" which is related to the learning area of "knowing simple relations and patterns" is included in both programs. The activities related to patterns in CKS require children to form patterns with materials after providing patterns from their real-life and environment. In TPEC, it is stated that the concept of patterns should be started by creating patterns with materials.

The ability to "represent numbers in various ways" is found as a learning goal in each program. This skill includes the principle of abstraction and is based on the idea that counting objects can be done without considering the relation of the objects with each other (Gelman and Gallistel, 1986).

While CKS contains the learning goal of "recognize that the quantity of a set of things stays the same regardless of the arrangement," TPEC does not. This goal is related to the principle of number conservation. According to approach constructed by Piaget, in order to acquire the concept of number, it is necessary to have the skill of number conservation.

The learning goals of "recognize numbers (1 to 10) in numerals and words and write numbers (1 to $10)$ in numerals" are included in CKS but not in TPEC.

The learning goal of "recognize that the quantity of a set of things is the 'same' irrespective of the starting point of counting" is included as a learning goal in CKS but not in TPEC. This learning goal includes counting objects in an irregular order.

The learning goal of "understand the relations between parts and the whole," which is related to the concept of fractions, is included in CKS but not in TPEC. The relations between parts and the whole is related to the development of a specific concept by understanding the whole of an object and its subsections (Veziroglu, 2017).

The learning goal of "name parts that form the whole in quantity" is included in CKS but not in TPEC. It can be said that this skill paves the way for addition and subtraction. The learning goal of "making simple addition and subtraction using objects" is involved in TPEC while is not involved in CKS. This learning goal is important in terms of the ability to make sense of the concepts of "increasing and decreasing."

The learning goals of "recognize different sizes and different positions of geometric shapes" is included in CKS but not in TPEC. Recognizing different dimensions and positions of geometric 
shapes may contribute to the development of sorting, classification, and comparison skills, which are early mathematical skills in children.

The learning goal of "use basic shapes to form figures" is included in CKS but not in TPEC. This shows that the learning outputs related geometry teaching expected from students in CKS are clearly expressed. The learning goal of "naming position (i.e. top/bottom, in front of/behind), direction (i.e. up/down, left/right) and distance (i.e. far/near)" is involved in both countries curriculum. This goal is important in terms of the development of mathematical thinking skills, such as spatial thinking, visualizing shapes in different positions, and visualizing movements.

Future studies can focus on the subject by comparing the curricula of more than two countries. In addition, learning guides as seen in Singapore program can be created for Turkey program. It will be useful to form different programs based on age levels (e.g., 5 years old, 6 years old) 


\section{GİRİŞ}

Erken çocukluk döneminde kazandırılan davranışlar, çocuğun ileriki yaşamında etkili olmakta(Baker, Mackler, Sonnenschein ve Serpell, 2001) ve daha üretken olmalarına katk1 sağlamaktadır (Cragg ve Gilmore, 2014). Okul öncesi dönemde matematik eğitimiyle çocukların hayatları boyunca kullanacakları problem çözme, ilişkilendirme ve iletişim kurma gibi becerilerin temellerinin atılması gerekmektedir; bu nedenle okul öncesi dönemindeki eğitimin içeriğinin iyi hazırlanmış olması ve kontrol edilip değerlendirilmiş olması önemlidir (Sarama ve Clements, 2006b). Çocuklar bahsedilen becerileri informal yollar ile öğrenebilmektedir. Fakat okul öncesi eğitimi ile bu beceriler formal eğitimin sağladığ uygun ve nitelikli deneyimlerle desteklenebilir (Ersan ve İvrendi, 2016). Bu açıdan bir eğitim sisteminin hedeflenen doğrultuda hazırlanan programlarının ihtiyaçları ne derece karşıladığının belirli zaman aralıklarıyla değerlendirilmesi ve bu değerlendirmelere göre uygulanan eğitim programlarının revize edilmesi gerekmektedir (Mueller ve File, 2019).

Öğrenme süreçlerinin yol haritaları olarak değerlendirilebilecek eğitim ve öğretim programları, öğretim sürecinin plan aşamasında ilk basamağını oluşturmaktadır (Krajcik, 2011). Eğitim programları okul öncesi, öğretim programları ise ilkokul, ortaokul, lise gibi farklı kademelerde hazırlanmaktadır. Türkiye'de daha önce planlı ve sistemli bir programın olmadığı okul öncesi eğitim programı ilk kez 1994’te yayınlanmıştır. Bu program 2002, 2005 ve 2013 yıllında güncellenmiştir (Dilek, 2016).

Ülkeler, kendi eğitim programlarını içinde bulunduğu zamanın ihtiyaçlarına ve gelecek hedeflerine dair politikalarını göz önüne alarak hazırlamaktadır. Bu kapsamda karşılaştırmalı eğitimden de yararlanırlar. Karşılaştırmalı eğitim, ulusların eğitim sistemleri arasındaki farkı ortaya çıkaran durumların analiz edilmesi ve bu durumların karşılaştırılması olarak tanımlamaktadır (Kandel, 1955). Çeşitli toplum, ülke, bölge ve tarihi dönemlerde uygulanan, eğitim sistemlerini bazen bir bütün olarak bazen de bazı yönleriyle karşlaştırarak benzer ve farklı yönleri tespit edip, eğitim teorisi, pratiği, politikası, planlaması ve reformlarında yararlanılma çalışmaları için karşılaştırmalı eğitim bilimi kullanılır (Postlethwaite, 1988). Ülkelerin eğitim sistemlerinin karşılaştırılmasında Uluslararası Okuma Becerileri Projesi (Project of International Reading Literacy Skills: PIRLS), Uluslararası Öğrenci Değerlendirme Programı (Programme for International Student Assessment: PISA) ve Uluslararası Matematik ve Fen Eğilimleri Araştırması (Trends in International Mathematics and Science Study: TIMSS) gibi uluslararası sınavlar yoğun bir şekilde kullanılmaktadır. Bu sınavlara katılan ülkeler hem öz değerlendirmelerini hem de diğer ülkelerin sonuçlarına göre bu ülkelerin değerlendirmelerini ve karşılaştırmalarını yapabilmektedir. Singapur, 
son y1llarda PISA, TIMMS ve PIRLS gibi uluslararası öğrenci değerlendirme sınavlarında üst sıralarda yerini almıstır. Singapur eğitim sistemi, McKinsey adlı araştırma kuruluşu tarafından 2010 yılında yapılan "Dünyanın En İyi Performans Gösteren Eğitim Sistemleri”" araştırmasında birçok ülkeyi geride bırakmıştır (Levent ve Yazıc1, 2014). Singapur'un eğitimde gösterdiği bu başarı diğer ülkelerin ilgisini çekmekte ve Singapur eğitim sistemiyle ilgili pek çok araştırmaya konu olmaktadır (Bozkurt, Kurt ve Tezcan, 2019; Erbilgin ve Boz 2013; Kabaran ve Görgen, 2016; Teo, Yan ve Ong, 2017; Kul ve Aksu, 2016; Marginson, 2011). Yapılan uluslararası sinavlarda Türk öğrencilerin matematiksel düşünme ve problem çözme becerilerinde de düşük seviyede olduğu gözlemlenirken, Singapurlu öğrencilerin ilk sırada yer aldığ1 görülmektedir. Erken yaşlarda çocuklara kazandırılan matematiksel bilgi ve kavramların, çocukların matematiksel düşünme ve problem çözme becerilerine katkı sağladığ1 (Akman, 2002) düşünüldüğünde, Türkiye ve Singapur okul öncesi matematik eğitiminin içeriklerinin karşılaştırılmasının gerekliliği bir araştırma konusu olarak karşımıza çıkmaktadır. Bu kapsamda çalışmada aşağıda verilen araştırma sorusuna cevap aranmıştır;

- Türkiye ve Singapur okul öncesi eğitim programlarının matematiksel içerikleri açısından benzerlik veya farklılıklar var midir? Varsa nelerdir?

Matematiğin öğrenilmesi, kavram gelişimi ile ilgili olup bu süreç somut deneyimlerle başlamaktadır; betimleme, örüntü oluşturma, karşılaştırma, sınıflandırma, eşitleme, sıralama, ölçme, gözlem yapma, semboller kullanma yani, rakam tanıma, rakam yazma ve grafik çizme gibi konular çocukların kavramları anlamalarına yardım ederek onların ileride matematiği anlayarak öğrenmelerini sağlamaktadır (İncikabı ve Tuna, 2012). Bu bakımdan okul öncesi öğretmenleri için bir yol gösterici olan programın matematik içeriği açısından eğitimde başarılı bir ülkeyle karşılaştırılarak analiz edilmesi ve belirlenecek olan sonuçların alan yazına sunulmasının okul öncesi eğitim uygulamalarına katkı sağlayacağı düşünülmektedir. Yapılan alan yazın incelemesinde, okul öncesi eğitim programlarının değerlendirilmesi ile ilgili çalışmaların yapıldığı belirlenmiştir (Elliott, Carr, Arlemalm-Hagser ve Park, 2017; Erdoğan, 2017; Wang, Elicker, McMullen ve Mao, 2008). Okul öncesi eğitim programındaki çevre eğitimine yönelik etkinlikler açısından ülkeler arasında karşılaştırmanın yapıldığı bir araştırmada (Akçay, 2006), Amerika, Almanya, Kanada, İsviçre ve Japonya'da uygulanan okul öncesi eğitim programları ile 2002 MEB Okul Öncesi Eğitim Programı incelenmiştir. Ancak okul öncesi eğitimi programının matematik içeriği açısından Türkiye ile Amerika arası analiz edildiği çalışma (İncikabı ve Tuna, 2012) dışında bir karşılaştırmalı eğitim çalışmasına rastlanılmamıştır. Bu yönüyle çalışmanın alan yazına katkı sunması beklenmektedir. 


\section{YÖNTEM}

Singapur ve Türkiye'nin okul öncesi eğitim programlarının matematik içeriklerinin incelendiği bu nitel çalısmada veri toplama yöntemi olarak doküman incelemesi kullanılmıştır. Doküman incelemesi çalışmalarında araştırılması hedeflenen olgu veya olgular hakkında bilgi içeren yazılı materyaller analiz edilerek veriler toplanır (Yıldırım ve Şimşek, 2006).

\section{İncelenen Dokümanlar}

Araştırma kapsamında 114 sayfadan oluşan Türkiye Okul Öncesi Eğitim Programı'ndaki (MEB, 2013) matematik içeriğiyle ilgili kısımlar ve 64 sayfadan oluşan Singapur Okul Öncesi Eğitim Programı Aritmetik Kılavuzunun (MOE, 2013) içerikleri incelenmiştir.

\section{Veri Analiz Yöntemi}

Bu çalışma kapsamında verilerin toplanması ve analiz süreci ile ilgili Creswell (2007) tarafindan önerilen Şekil 1'deki adımlar uygulanmıştır.

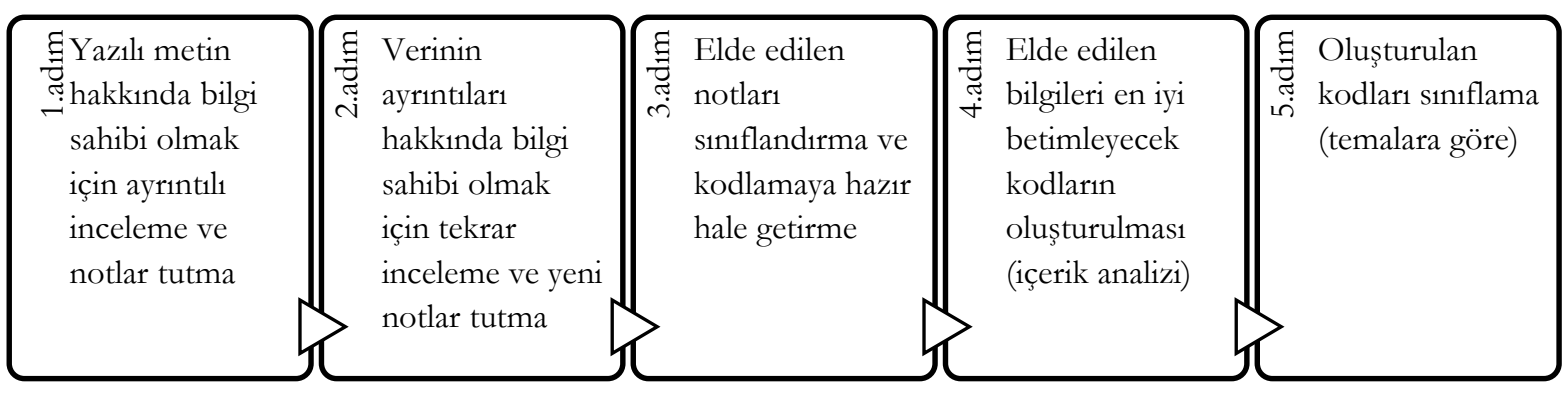

Şekil 1. Araştırmada kullanılan veri toplama ve analiz adımları (Creswell, 2007)

Verilerin analizinde içerik analizi yöntemi kullanılmıştır. İçerik analizi incelenen dokümanlarda yer alan ve araştırma konusu ile ilgisi olduğu düşünülen kelime veya cümlelerin analiz birimi olarak ayıklanması ve bu analiz birimlerini isimlendirilmek suretiyle kodlanmasıdır (Marshall ve Rossman, 1995). Bu çerçevede çalışmaya yön veren araştırma sorusuna cevap aranırken araştırma konusuna dâhil programlardaki kazanımlar öncelikle dört öğrenme alanı altında sınıflandırıldığı görülmüştür. $\mathrm{Bu}$ öğrenme alanları ve içerikleri Tablo 1'de verilmiştir. 
Tablo 1. Kazanımları sınıflandırılmada belirlenen öğrenme alanlarının içerikleri

\begin{tabular}{|c|c|}
\hline Öğrenme Alanı & Alt Öğrenme Alanı \\
\hline Basit ilişkileri ve örüntüleri tanıma ve kullanma & $\begin{array}{ll}\text { - } & \text { Temel sayı öncesi kavramlar } \\
\text { - } & \text { Örüntü oluşturma } \\
\text { - } & \text { Zaman ile ilgili kavramlar } \\
\text { - } & \text { Grafik oluşturma ve okuma } \\
\end{array}$ \\
\hline Günlük deneyimlerde sayıları kullanma & $\begin{array}{l}\text { - } 1 \text { den 10’a kadar sayılar } \\
\text { - Nesne miktarlarını sayılarla eşleştirme } \\
\text { - } \text { Sayıları düzenli sayma } \\
\text { - } \quad \text { Söylenen son sayının kümedeki nesne miktarı olduğunu bilme } \\
\text { - } \quad \text { Saymanın kümedeki nesnelerin ilişkisinden bağımsız } \\
\text { olduğunu bilme } \\
\text { - Saymaya kümedeki nesnelerden herhangi biri ile başlanacağını } \\
\text { - } \quad \text { bilme } \\
\text { - Sayı korunumunu anlama }\end{array}$ \\
\hline $\begin{array}{l}\text { Günlük deneyimlerdeki temel şekilleri ve temel } \\
\text { mekânsal kavramları tanıma ve kullanma }\end{array}$ & $\begin{array}{ll}\text { - } & \text { Temel konum kavramları } \\
\text { - } & \text { Temel geometrik şekiller } \\
\end{array}$ \\
\hline Ölçme birimlerini tanıma ve kullanma & $\begin{array}{l}\text { - Ölçmek için standart ve standart olmayan araçları kullanma } \\
\text { - Tahminlerde bulunmak için ölçmeye yönelik referanslar } \\
\text { geliştirme }\end{array}$ \\
\hline
\end{tabular}

Tablo 1'de verilen bu öğrenme alanlarının üç tanesi SOEP'te belirtilen matematik kazanımlarının ana başlıkları olan öğrenme alanlarıdır. Dördüncü öğrenme alanı ise TOEP’teki ölçme becerisi kazanımının bu üç öğrenme alanı dışında kalmasından dolayı oluşturulmuştur. İncelenen programların matematik içerikleri, öğrenme ve alt öğrenme alanlarına göre kategorize edilmiştir. İncelenen programlardaki kazanım ve açıklamaların veriliş biçimine dair örnek durumlar EK-1,2 ve 3’te sunulmuştur. Kategorize edilen kazanımlar bulgular kısmında tablolar aracıllğıyla iki ülkenin karşılaştırılması biçiminde verilmiştir. Ayrıca günlük deneyimlerde sayıları kullanma öğrenme alanına dair karşılaştırmada TOEP'te bulunan üç kazanımın göstergeleri SOEP’te kazanım olarak bulunduğundan ve bu üç kazanımdan bazılarının sadece birkaç göstergesi her iki ülke programında uyuştuğundan bu öğrenme alanındaki kazanımların göstergeleri de tablolar aracıllğıyla karşılaştırılmıstır.

Analizlerin güvenirliği kapsamında incelenen programların içeriklerine dair her bir başlıktaki kodlamalar matematik eğitimi alanında çalışan iki araştırmacı tarafından bağımsız olarak yapılmış ve elde edilen bulgular karşılaştırılmıştır. Karşılaştırmalarda "Görüş birliğị” ve "Görüş ayrrllı̆̆ı" sayıları tespit edilerek, araştırmanın güvenirliŭi "Görüş birliği / (Görüş birliği + Görüş ayrıllı̆ı)" formülü (Miles ve Huberman, 1994) kullanılarak hesaplanmıştır. Hesaplama sonucunda elde edilen 60 kodda \% 96 oranında bir uzlaşma olduğu görülmüştür. Bu oran güvenilir olarak kabul edilmesine 
rağmen görüş ayrılığına düşülen kodlar üzerinde çalışılarak ortak bir görüşe varılmıştır. Bu şekilde veri analizinin güvenirliği artırılmıştır.

\section{BULGULAR}

Verilerin analizlerinden elde edilen bulgular Tablo 1'de verilen öğrenme alanları başlıkları altında verilmiştir.

\section{Basit İlişkileri ve Örüntüleri Tanıma ve Kullanma Öğrenme Alanına İlişkin Bulgular}

İncelenen programlarda yer verilen basit ilişkileri ve örüntüleri tanıma ve kullanma öğrenme alanının kazanımları Tablo 2'de verilmiştir.

Tablo 2. Basit ilişkileri ve örüntüleri tanıma ve kullanma öğrenme alanına ait kazanımlar

\begin{tabular}{|c|c|}
\hline TOEP & SOEP \\
\hline - Nesne veya varlıkları özelliklerine göre eşleştirir. & - $\quad$ Nesneleri özelliklerine göre eşleştirir. \\
\hline - Nesne veya varlıkları özelliklerine göre gruplar. & - $\quad$ Nesneleri özelliklerine göre sinıflandırır. \\
\hline - Nesne veya varlıkların özelliklerini karşılaştırır. & - $\quad$ Nesneleri özelliklerine göre karşılaştırır. \\
\hline - Nesne veya varlıkları özelliklerine göre sıralar. & - Nesneleri boyutlarına ve oluş sırasına göre sıralar. \\
\hline - Nesnelerle örüntü oluşturur. & - Temel örüntüleri tanır, devam ettirir ve oluşturur. \\
\hline - Zamanla ilgili kavramları açıklar. & - \\
\hline - Nesne/sembollerle grafik hazırlar. & - \\
\hline
\end{tabular}

Tablo 2 incelendiğinde, basit ilişkileri ve örüntüleri tanıma ve kullanma öğrenme alanında TOEP ve SOEP'te ortak olan 5 kazanım, TOEP'te olup SOEP' te olmayan 2 kazanım bulunduğu görülmektedir. Bu 2 kazanım SOEP’te gösterge olarak bulunmaktadır. Örneğin TOEP’te olup SOEP’te olmayan “Zamanla ilgili kavramları açılar” kazanımı SOEP’te bulunan "Nesneleri boyutuna, uzunluğuna ve oluş sırasına göre sıralar" kazanımının altında "Bir olayı oluş sırasına göre sıralar", "Günün farklı zaman dilimlerinin isimlerini söyler", "Haftanın günlerini sırayla söyler” ve "Yılın aylarını isimlendirir ve sıralar" göstergeleriyle verilmiştir. Benzer şekilde TOEP’te "Nesne/sembollerle grafik hazırlar." kazanımı varken SOEP’te bu kazanım yoktur. Fakat bu kazanımın grafik oluşturma ve okuma göstergeleri, SOEP’te nesneleri eşleştirme, karşılaştırma, sıralama ve örüntü oluşturma kazanımlarının uygulamalarına dair verilen örneklerde geçmektedir.

\section{Günlük Deneyimlerde Sayıları Kullanma Öğrenme Alanına İlişkin Bulgular}

İncelenen programlarda yer verilen günlük deneyimlerde sayıları kullanma öğrenme alanının kazanımları Tablo 3’te verilmiştir. 
Tablo 3. Günlük deneyimlerinde sayıları kullanma alanına ait kazanımlar

\begin{tabular}{|c|c|}
\hline TOEP & SOEP \\
\hline - Nesneleri sayar & $\begin{array}{l}\text { - En az } 10 \text { 'a kadar sayar } \\
\text { - 10'a kadar eşlemeli sayma yapar } \\
\text { - İki nesne grubunun miktarını karşılaştırır ve "daha fazla", } \\
\text { "daha az/az sayıda" ve "aynı" kelimelerinin uygun olanını } \\
\text { kullanır } \\
\text { - Sayıların (1'den 10'a kadar) okunuşunu ve yazılışını bir nesne } \\
\text { grubunun miktarıyla eşleştirir. } \\
\text { - Bir grup nesnenin miktarının, saymanın başlangı̧ yerine } \\
\text { bakıllmaksızın "aynı" olduğunu görür } \\
\text { - Bir grup nesnenin miktarının, düzenlemeye bakılmaksızın } \\
\text { aynı kaldığını görür (miktarın korunumu) } \\
\text { - Sayıları (1'den 10'a kadar) sembollerle ve kelimelerle tanır. } \\
\text { - Sayılara karşılık gelen sembolleri yazabilir (1 den 10'a kadar). }\end{array}$ \\
\hline - Parça-bütün ilişkisini kavrar & \\
\hline $\begin{array}{l}\text { - Nesneleri kullanarak basit toplama ve çıkarma } \\
\text { işlemlerini yapar. }\end{array}$ & $\begin{array}{l}\text { - Bütünü oluşturan parçaları isimlendirir (2 ile 3'ün toplamı } 5 \\
\text { yapar) }\end{array}$ \\
\hline
\end{tabular}

Tablo 3 incelendiğinde, günlük deneyimlerde sayıları kullanma öğrenme alanında TOEP’te 3 kazanım bulunurken SOEP’te 9 kazanım bulunmaktadır. Karşılaştırmanın bu durumu kazanımların beklediği becerinin ülkelerde olmadığı anlamına gelmemektedir. Örneğin TOEP’te bulunan “Nesneleri sayar” kazanımının göstergeleri SOEP’te bulunduğu gibi SOEP’te bulunan kazanımların göstergeleri de TOEP'te bulunmaktadır. Bu göstergeler Tablo 4, Tablo 5, Tablo 6 ve Tablo 7'de verilmiştir.

Tablo 4. "Nesneleri sayar" kazanımına ait göstergelerin ülkelerin eğitim programlarında yer alma durumları

\begin{tabular}{|c|c|c|}
\hline Göstergeler & TOEP & SOEP \\
\hline 1'den 10'a kadar ileriye birer birer ritmik sayar & $\checkmark$ & $\checkmark$ \\
\hline 1'den 10'a kadar geriye birer birer ritmik sayar & $\checkmark$ & $x$ \\
\hline Nesne miktarını birer birer sayar & $\checkmark$ & $\checkmark$ \\
\hline Belirtilen sayı kadar nesneyi gösterir & $\checkmark$ & $\checkmark$ \\
\hline Saydığı nesnelerin kaç tane olduğunu söyler & $\checkmark$ & $\checkmark$ \\
\hline Sıra bildiren sayıları söyler & $\checkmark$ & $\checkmark$ \\
\hline 10'a kadar olan sayılar içerisinde bir sayıdan önce gelen sayıyı söyler. & $\checkmark$ & $\checkmark$ \\
\hline 10'a kadar olan sayılar içerisinde bir sayıdan sonra gelen sayıyı söyler. & $\checkmark$ & $\checkmark$ \\
\hline $\begin{array}{l}\text { İki nesne grubunun miktarını karşılaştırır ve "daha fazla", "daha az / az sayıda" ve "aynı" } \\
\text { kelimelerinin uygun olanını kullanır }\end{array}$ & $\checkmark$ & $\checkmark$ \\
\hline $\begin{array}{l}\text { Sayı miktarlarını çeşitli şekillerde temsil eder (ör. Nesneler, parmaklar, } 10 \text { tabanlı bloklar, onluk } \\
\text { kartlar, çeltik işaretleri kullanarak) }\end{array}$ & $x$ & $\checkmark$ \\
\hline Bir sayının söylenişi ile nesne gruplarının miktarını eşleştirir & $\checkmark$ & $\checkmark$ \\
\hline 1'den 10 kadar olan nesne grupları ile rakamları (sayının sembolünü) eşleştirir & $\checkmark$ & $\checkmark$ \\
\hline Sayının kelime olarak yazılışını rakam olarak yazılışı ile veya nesne grubunun miktarıyla eşleştirir & $x$ & $\checkmark$ \\
\hline Aynı miktarda olup düzeni farklı olan nesne gruplarının miktarının aynı olduğunu fark eder. & $x$ & $\checkmark$ \\
\hline 1'den 10 'a kadar olan sayıları sembollerle ve kelimelerle tanır & $x$ & $\checkmark$ \\
\hline Sayıları sembolik olarak oluşturur (1 den 10 a kadar) & $x$ & $\checkmark$ \\
\hline Nesnelerin miktarının, saymanın başlangıç yerine bakılmaksızın "aynı" olduğunu görür. & $x$ & $\checkmark$ \\
\hline
\end{tabular}


Tablo 4'te görüldüğ̈ gibi “1'den 10 kadar olan nesne grupları ile rakamları (sayının sembolünü) eşleştirir.” cümlesi SOEP'te kazanım olarak bulunurken TOEP'te bulunmamaktadır. Fakat TOEP’te "Nesne veya varlıkları özelliklerine göre eşleştirir” kazanımının açıklamasında nesne veya nesne gruplarını uygun rakamla eşleştirme etkinliklerinin en son yapılacak etkinlikler olduğu söylenmektedir. "Sıra bildiren sayıları söyler” ifadesi TOEP’te gösterge cümlesi olarak bulunurken SOEP'te örnek etkinliklerde nesneleri sıralarken çocukların sıra bildiren sayıları kullanabileceği şeklinde ifade edilmiştir. SOEP’te ki "İki nesne grubunun miktarını karşılaştırır ve "daha fazla", “daha az/az" ve “aynı” kelimelerinin uygun olanını kullanır” kazanımı TOEP’te "Nesne veya varlıkları miktarına göre ayırt eder, karşılaştırır” kazanımın göstergesi olarak bulunmuştur. "Sayı miktarlarını çeşitli şekillerde temsil eder” ifadesi kazanım olarak TOEP ve SOEP’te bulunmamıştır.

Tablo 5. "Parça-bütün ilişkisini kavrar" kazanımına ait göstergelerin ülkelerin eğitim programlarında yer alma durumlar1

\begin{tabular}{lcc}
\hline \multicolumn{1}{c}{ Göstergeler } & TOEP & SOEP \\
\hline Verilen iki yarımı birleştirerek bütün oluşturur & $\checkmark$ & $\mathbf{x}$ \\
Yarım ve bütün nesneleri gösterir & $\checkmark$ & $\mathbf{x}$ \\
Bir bütünün parçalarını söyler & $\checkmark$ & $\checkmark$ \\
Bir bütünü parçalara böler & $\checkmark$ & $\checkmark$ \\
Parçaları birleştirerek bütün elde eder & $\checkmark$ & $\checkmark$ \\
\hline
\end{tabular}

Tablo 5’te görüldüğü gibi “Parça-bütün ilişkisini kavrar” kazanımı TOEP’te kesir kavramını içeren bir kazanım olarak bulunmaktadır. Kazanımın açıklamasında yapbozların, insan vücudunun ve yüzünün, hayvanların, yiyeceklerin ve çocukların günlük hayatta sıklıkla kullandığı gerçek nesnelerin ve oyuncakların parça bütün ilişkisinin kavranmasında kullanılabileceği belirtilmektedir. $\mathrm{Bu}$ kazanımın göstergelerinin tamamı TOEP’te bulunurken SOEP’te "Bütünü oluşturan parçaları isimlendirir" kazanımının göstergeleri olarak verilmiştir. Ancak SOEP’te iki yarımı birleştirerek bütün oluşturma ve yarım ve bütün nesneleri göstermeye yönelik göstergelerin altı ayrıca çizilmemiştir. SOEP’te bir sayının daha küçük parçalardan oluştuğu kavratmaya çalışan bir kazanım olarak bulunmaktadır. SOEP’teki bu kazanımın toplama ve çıkarma işlemlerine zemin hazırladığ1 belirtilmektedir. SOEP’te bulunan “Bütünü oluşturan parçaları isimlendirir” kazanımının "Parçaları birleştirerek bütünü elde eder” göstergesi TOEP’te "Nesneleri kullanarak basit toplama ve çıkarma işlemlerini yapar” kazanımının örneklerinde bulunmaktadır. 
Tablo 6. "Nesneleri kullanarak basit toplama ve çıkarma işlemlerini yapar" kazanımına ait göstergelerin ülkelerin eğitim programlarında yer alma durumları

\begin{tabular}{lll}
\hline Göstergeler & TOEP & SOEP \\
\hline 1'den 10'a kadar olan nesneleri kullanarak toplama yapar & $\checkmark$ & $\checkmark$ \\
1 den 10 kadar olan nesneleri kullanarak çıkarma yapar & $\checkmark$ & $\mathbf{x}$ \\
\hline
\end{tabular}

TOEP'te verilen "Nesneleri kullanarak basit toplama ve çıkarma işlemlerini yapar" kazanımı nesnelerle yapılan toplama ve çıkarma işlemlerini ifade etmektedir, rakamlar ve sembollerle işlem yapılmamaktadır. Bu kazanım SOEP’te bulunmamasına rağmen kazanımın göstergelerine "Bütünü oluşturan parçaları isimlendirir” kazanımının etkinlik örneklerinde ve açıklamalarında rastlanılmıştır (Resim 4).

\begin{tabular}{|c|c|c|}
\hline $\begin{array}{l}\text { Anahtar bilgi / beceriler } \\
\text { / planlar }\end{array}$ & $\begin{array}{l}\text { Öğrenme } \\
\text { hedefleri }\end{array}$ & Etkinlikler \\
\hline $\begin{array}{l}\text { Bütünü olussturan parçaları } \\
\text { isimlendirir (örneğin } 2 \text { ile } \\
\text { 3’ün toplamı } 5 \text { yapar) }\end{array}$ & $\begin{array}{l}\text { 5'e } \\
\text { tamamlanan } \\
\text { parçaları } \\
\text { belirler }\end{array}$ & $\begin{array}{l}\text { - Çocukları eşleştirin ve her birine } 5 \text { torba küp verin. Bir çocuk } \\
\text { çantasından bir miktar küp alacak ve diğer çocuk } 5 \text { yapmak için } \\
\text { kendi çantasından doğru sayıda küp almak zorunda kalacaktır. } \\
\text { • Bir yol üzerindeki bir olayı temsil edecek türden öyküyü kurup } \\
\text { sunmak için araba ve sayma tahtası gibi nesneleri kullanarak bir sayı } \\
\text { öyküsü anlatın.3 kırmızı araba var. Yolda } 5 \text { araba var. }\end{array}$ \\
\hline
\end{tabular}

Resim 4: SOEP’ teki “Bütünü oluşturan parçaları isimlendirir” kazanımının etkinlik örnekleri

Resim 4'te görüldüğ̈̈ gibi 2 yeşil araba ile 3 kırmızı arabanın yolda bulunduğunu, buna göre yolda 5 arabanın olduğu ifade edilerek toplama işlemi yapılmaktadır.

\section{Günlük Deneyimlerdeki Temel Şekilleri ve Temel Mekânsal Kavramları Tanıma ve Kullanma Öğrenme Alanına İlişkin Bulgular}

Günlük deneyimlerdeki temel şekilleri ve temel mekânsal kavramlanı tanıma ve kullanma öğrenme alanının iki ülke bazındaki kazanımları ve bu kazanımların karşılaştırılması Tablo 7'de verilmiştir.

Tablo 7. Günlük deneyimlerdeki temel şekilleri ve temel mekânsal kavramları tanıma ve kullanma alanına ait kazanımlar

\begin{tabular}{ll}
\hline TOEP & \multicolumn{1}{c}{ SOEP } \\
\hline Mekânda konumla ilgili yönergeleri uygular. & $-\quad \begin{array}{l}\text { Konumu (üst / alt, ön / arkada), yönü (yukarı / aşağı, sol / să̆) } \\
\text { ve mesafeyi (uzak / yakın) isimlendirir. }\end{array}$ \\
\hline Geometrik şekilleri tanır. & $-\quad \begin{array}{l}\text { Dört temel şekli tanır (yani daire, kare, dikdörtgen ve üçgen) } \\
\text { Farklı şekilleri oluşturmak için temel şekilleri kullanır (örneğin, } \\
\text { iki kare ve bir üçenden kayıl oluşturma). }\end{array}$ \\
\hline
\end{tabular}

TOEP'te "Mekânda konumla ilgili yönergeleri uygular" kazanımına karşılık SOEP'te "Konumu (üst / alt, ön / arkada), yönü (yukarı / aşağı, sol / sağ) ve mesafeyi (uzak / yakın) isimlendirir”" kazanımı bulunmaktadır. TOEP'te bu kazanımın göstergeleri “Mekânda konumla ilgili yönergeleri uygular, Yönergeye uygun olarak nesneyi doğru yere yerleştirir, Nesnenin mekândaki konumunu söyler, Harita ve krokiyi kullanır, Mekânda konum alır” şeklinde belirtilmiştir. SOEP’te ise kazanım 
altında gösterge bulunmaz iken konum ile ilgili verilen etkinlik örneğinde TOEP’teki göstergeleri içerdiği görülmektedir.

TOEP’teki “Geometrik şekilleri tanır” kazanımını SOEP’te iki kazanım karşılamaktadır. TOEP’te bu kazanım geometrik şekillerin ismini ve özelliklerini söyleme, geometrik şekillere benzeyen nesneleri gösterme becerilerini içermektedir. SOEP'te ki iki kazanım ise TOEP'teki beceriler yanında bir geometrik şeklin farklı boyutlarını tanıma, geometrik şeklin farklı pozisyonlarında özelliğinin değişmeyeceğini bilme ve temel şekiller kullanarak farklı şekiller oluşturma becerilerini içermektedir. TOEP’te ise SOEP’te bulunan bu becerilere rastlanılmamıştır. Ayrıca “Geometrik şekilleri tanır” kazanımın içeriğinde her iki ülkede de daire, kare, dikdörtgen ve üçgen bulunurken TOEP’te elipste bulunmaktadır.

\section{Ölçme Birimlerini Tanıma ve Kullanma Öğrenme Alanına İlişkin Bulgular}

Ölçme birimlerini tanıma ve kullanma öğrenme alanında TOEP’te bir kazanım bulunurken SOEP'te kazanım bulunmamaktadır. Aynı şekilde TOEP incelendiğinde "Nesneleri ölçer" kazanımının "Ölçme sonucunu tahmin eder, Ölçme sonucunu söyler, Ölçme sonuçlarını tahmin ettiği sonuçlarla karşılaştırır, Standart olmayan birimlerle ölçer, Standart ölçme araçlarının neler olduğunu söyler" şeklinde 5 göstergesi olduğu görülmektedir ve bu göstergeler deSOEP’te bulunmamıştır.

SOEP'te bu kazanıma ait kazanım cümlesine rastlanılmamıştır. Fakat NCTM standartlarında bulunan ölçme kavramı, zamanı ve uzunlukları karşılaştırma becerileri içermektedir ve bu beceriler SOEP’te de bulunmaktadır. Bu bağlamda SOEP'te ölçme becerisi olmadığı söylenemez.

\section{TARTIŞMA}

Türkiye ve Singapur Okul Öncesi Eğitim Programlarının matematik içerikleri açısından benzerlik veya farklılıkların araştırıldığı bu çalışmadan elde edilen bulgular öğrenme alanlarına göre tartışılmıştır.

\section{Temel İlişkileri ve Örüntüleri Tanıma ve Kullanma}

TOEP ve SOEP’te basit ilişkileri ve örüntüleri tanıma ve kullanma öğrenme alanı içeriğinde iki programda da eşleştirmeye yer verilmiş olması çocuklarda sayma kavramına temel oluşturması açısından önemlidir. Birebir eşleştirme mantıklı saymayla ilişkili ve sayı kavramının en önemli temel bileşenidir (Chalesworth ve Lind, 2003). Ayrıca çocuğun var olan doğal merakından ve keşfetme 
becerilerinden yararlanılarak okul öncesi dönemde kazandırılan temel kavram ve beceriler çocuğun yaşamındaki öğrenmelerini ve gelişimini desteklemektedir (Gelman ve Gallistel, 1986). Bu bağlamda çocukların matematiksel kavram ve becerilerini geliştirmek ve yaşamlarında karşılarına çıkacak soyut matematiksel kavramları anlayabilmeleri için ön beceriler olarak tanıma, adlandırma, karşılaştırma, eşleştirme, gruplandırma, sıralama ve ayırt etme becerileriyle ilgili çalışmalar yapmaları (Uyanık ve Kandır, 2010) gereklidir.

Sınıflandırma becerisine dair kazanımlar her iki ülke programında da yer almaktadır. Sınıflandırma bir düşünme becerisidir ve küme kavramını temel almaktadır (Olkun ve Uçar, 2012). Küme kavramı da matematikteki birçok kavrama temel oluşturabildiği için önemlidir (Nesin, 2017). Öğrenme kuramcıları tarafından bilişsel gelişimin büyük bir oranda sınıflandırma becerisine dayandığı savunulmaktadır (Alcock ve Simpson, 2017). Bu bağlamda sınıflandırma becerisi çocukların matematik kavram ve becerilerini geliştirmeleri için ve ileriki öğrenmelerinde karşılaşacakları soyut matematiksel kavramları anlayabilmeleri için gereklidir.

SOEP’te çocukların sınıf veya dış ortamlarda örüntü örnekleri aramaları ve çocukların gerçek hayatlarından ve çevrelerinden örüntü örnekleri verildikten sonra materyallerle örüntü oluşturmaları beklenmektedir. TOEP’te ise örüntü kavramına materyallerle örüntü oluşturma ile başlanması gerektiği ifade edilmektedir. Örüntü oluşturma bir sıralama biçimi (MOE, 2013) olduğundan sıralama becerisi gelişmemiş olan bir çocuğun örüntüleme yapabilmesi beklenilemez (Akman, 2002). Örüntüler, saymanın ve geometrinin bir tasviridir ve örüntüler arasındaki bağlantıları, günlük hayatta pek çok yerde görmek mümkündür. Örüntü aramayı ve onların nasıl tarif edileceğini, başka bir duruma aktarılacağını ve genişletileceğini öğrenmek, aynı zamanda matematik yapmanın ve cebirsel düşünmenin bir parçasıdır (Van de Walle, Karp ve Bay-Williams, 2016). Bu bağlamda erken çocukluk döneminde gerçek hayat ve çevreden örnekler verilecek şekilde örüntü çalışmalarının yapılması önemlidir.

SOEP'te basit örüntüleri tanıma, genişletme ve oluşturmaya dair bir kazanım verilmiştir. TOEP'te ise nesnelerle örüntü oluşturmaya dair vurgu kazanımın açıklamasında verilmiştir. Çocuklar örüntüyü dört aşamada keşfetmektedir. Önce örüntüyü tanıma, tanımlama, genişletme ve son aşama ise kendi örüntüsünü oluşturmaktır (Haciibrahimoğlu, 2017a). Bir örüntü kuralını başka bir örüntüde görebilme ve kullanma, sadece aritmetikten cebire geçmenin değil, bunun yanında cebirsel düşünmenin önemli işaretlerinden biridir (Akkan ve Çakıroğlu, 2012). Örüntüleri tanıma becerisi, devam ettirme becerisi ve oluşturma becerisi; matematiksel ilişkileri görmekte, genelleme yapmakta, 
matematiğin düzen ve mantığını anlamaya zemin oluşturduğundan (Haciibrahimoğlu, 2017a) bu içeriğin aşamaları dikkate alınarak verilmesi önemlidir.

\section{Günlük Deneyimlerde Sayıları Kullanma}

Sayma becerileri kazanma ve sayı hissi geliştirme, çocukların sayı kavramını ve bunların ilişkilerini anlamalarına yardımcı olur (MOE, 2018). Sayı duyusu, sayılar ve sayılar arasındaki ilişkileri anlama ve esnek bir biçimde kullanmayı içermektedir (Le Corre ve Carey, 2007). Bu bağlamda alan yazın incelendiğinde, sayma becerisi ve sayı hissi gelişimi için temel ilkelerin kazanılması gerektiği görülmektedir (Akkaya, 2019); bu ilkeler Gelman ve Gallistel (1986) tarafından ileri sürülen bire bir eşleme, sabit sıra, kardinal sayı, soyutlama ve sıranın önemsizliği ilkeleridir. Bu ilkeler doğrultusunda iki programa da baktığımızda ileriye birer birer ritmik saymanın göstergesi sayıların ritmik ezberlenme becerisini içermektedir. Bu beceri sabit sıra ilkesine dayanmaktadır. Ezbere saymanın çocukların sayı sayma becerilerinin ve sözcük dağarcıklarının gelişimi bakımından önemli (Taşkın, 2017) olduğu ve çocukların zamanla sayıların sıralarının sabit olduğunu fark etmesi (Akkaya, 2019) bakımından düşünüldüğünde programlarda yer verilmiş olması önemlidir.

TOEP ve SOEP’te günlük deneyimlerde sayıları kullanma öğrenme alanının kazanımları incelenmiş ve aralarında fark olduğu görülmüştür. İki nesne grubunun miktarlarını karşılaştırmaya yönelik kavramlar TOEP'te gösterge olarak bulunurken SOEP'te kazanım olarak bulunmaktadır. "Daha fazla", "daha az” ve “ aynı" kavramları, sayı kavramını genel olarak anlamaya katkıda bulunan temel ilişkilerdir (Van de Walle, Karpve Bay-Williams, 2016). Saymanın gelişiminde nicelik/miktar algilama ilk evre (Akkaya, 2019) olduğundan çocuklar formal eğitime başlamadan önce ilişkisel fikirler geliştirmeye başlamaktadır ve çocuklarda sayı kavramı gelişmeden önce, 1 yaşındaki çocuklar kendilerine görsel olarak sunulmuş olan nesnelerin azlık-çokluğunu ayırt edebilmektedirler (Baroody, 2004). Griffin (2004) nesne gruplarından hangisinin neden fazla olduğunu açıklayabilen çocukların, matematiksel düşünme ve akıl yürütme becerisinin gelişmeye başladığının güzel bir örneği olduğunu belirtmiştir. Aynı zamanda basamak değeri, işlem ve kesir kavramlarının anlaşılması için bir ön koşuldur (Akkaya, 2019).

TOEP'te nesne miktarını birer birer sayma becerisi gösterge olarak bulunurken SOEP'te rasyonel sayma ve sayıları temsil eden sembolik gösterimler kullanarak sayma kazanım olarak bulunmaktadır. Çocuklar için anlayarak sayma, nesneleri saydıkları zaman hiçbir nesneyi saymamazlık yapmamaları ve aynı nesneyi birden fazla kez saymamalarıdır (Polonsky, Freedman, Lesher ve Morrison, 1995). Bu gösterge için her iki programda da nesnelerin dokunularak sayılması gerektiği belirtilmiştir. Ritmik saymanın ötesinde sayıları temsil eden sembolik gösterimler kullanılarak saymak, tek seferde 
her bir sayının bir nesneyle eşleştirilmesini gerektirir. Doğru şekilde ezberden sayım ve bire bir eşleştirerek sayma sayıların sembolik gösterimlerini kullanarak saymanın temelidir (MOE, 2018). Sayımdaki son sayının sadece sayılan son ögeyi etiketlemekle kalmayıp, aynı zamanda gruptaki nesnelerin sayısını da temsil ettiğini öğrenirler. NCTM’ye (2000) göre çocukların sayı hissini kazanmaları anlamlandırarak saymaya bağlıdır (Van de Walle, Karpve Bay-Williams, 2016). Polonsky ve arkadaşlarına (1995) göre anlamlandırarak sayma becerisi sayıların doğru dizilimini bilme, bir grup nesne sayılırken her nesnenin sadece bir defa sayıldığını bilme, son sayılan nesneye verilen sayının tüm nesnelerin toplamını temsil ettiğini bilme yeterliliklerini barındırmaktadır. $\mathrm{Bu}$ bağlamda iki ülkenin okul öncesi programında da bire bir eşleme ve kardinal sayı ilkelerini içermektedir. SOEP’te gösterge olarak bulunan sayı miktarlarını çeşitli şekillerde temsil etme, TOEP’te hiçbir şekilde bulunmamaktadır. Bu beceri soyutlama ilkesini içermektedir; bu ilkeye göre bir kümeyi oluşturan elemanların birbiriyle ilişkisi olmadan sayım yapılabilir (Linder, PowersCostello ve Stegelin, 2011).

SOEP'te hem aynı miktarda olan hem de düzeni farklı olan nesne gruplarının miktarının aynı olduğunu fark etmeye dair kazanım bulunurken TOEP'te bulunmamaktadır. Bu kazanım sayı korunumu ilkesi ile ilgilidir. Sayı korunumu, sayılacak nesnelerin dağılımı ne olursa olsun sayının aynı kalacağını bilmesidir (Arnas ve Aslan, 2004). Çocuğun sayı kavramını kazanabilmesi için sayı korunumunu kazanmış olması gerekir. Sayı korunumu kazanan çocuklar şipşak sayma (subitizing) becerisi de kazanmış olurlar (Olkun, Fidan ve Özer 2013). Şipşak sayma, bir gruptaki nesnelerin sayısın, her bir nesneyi teker teker saymadan belirleme becerisini ifade eder. Bu bağlamda okul öncesi programında bu kazanımın bulunmasının gerekli olduğu düşünülmektedir.

SOEP'te sayıları sembollerle ve kelimelerle tanıma ve rakamlarla sayı oluşturmaya dair kazanım olarak bulunurken TOEP'te bulunmamaktadır. Bu kazanımın TOEP'te bulunmaması hazır bulunuşlukla ilgili olabilir. Çünkü rakamları tanımak ve yazmak birbirinden farklı becerilerdir; yazmak, o rakamı özel işaretler veya harflerle ifade etmek iken, tanımak ise çocuğun rakamla ilgili, doğru ve tam bilgisinin bulunmasıdır (Taşkın, 2017). Fizyolojik olgunlukları henüz tamamlanmamış ise çocuklar rakamları tanısalar bile yazamayabilirler (Dewey ve Tupper, 2004).

SOEP’te bir grup nesnenin miktarının, saymanın başlangıç yerine bakılmaksızın 'aynı' olduğunu görmeye dair kazanım bulunurken TOEP’te bulunmamaktadır. Bu kazanım ifadesi, sezgisel olarak saymaya ve çocuklarda erken yaşlardan itibaren sayı hissinin oluşmasına katkı sağlar. Bu ilke bir grubu oluşturan nesnelerin hangisinden saymaya başlanırsa başlansın, o grubu oluşturan nesne sayısının değişmeyeceğini belirtir (Gelman ve Galistel, 1983). 
TOEP’te parça bütün ilişkisini kavramaya dair kazanım bulunurken SOEP’te bulunmayan kesir kavramını içermektedir. Bu bağlamda TOEP’te bu kazanımının bulunmuş olması önemlidir. Çünkü parça- bütün ilişkisi bir nesnenin bütününü ve alt bölümlere ayrılmış halini görerek buna özgü bir kavram geliştirilmesiyle ilgilidir (Veziroğlu, 2017). TOEP’te yapbozların, insan vücudunun ve yüzünün, yiyeceklerin, gerçek nesnelerin ve oyuncakların parça bütün ilişkisinin kavranmasında yararlı olacağı belirtilmiştir. Parça ve bütün üzerine çalışılarak elde edilen tecrübeler, çocukların işlem öncesi dönemde geliştirdikleri bakış açılarını somut işlemler dönemindeki bakış açısına dönüştürmelerine ve bütünün tüm parçaların toplamından daha fazla olmayacağına ilişkin anlayışı geliştirmelerini sağlamaktadır (Charlesworth ve Lind, 2003). Çocuklar günlük yaşantılarında sıklıkla karşılaştıkları parça bütün ilişkilerini zaman içinde nesnelerin sayıları, miktarları ve boyutları için kullanır hale gelirler. Böylece ilköğretim ve daha ileriki kademelerdeki matematik eğitiminde kullanacakları bölme, çarpma, kesirler, rasyonel sayılar gibi konulara temel teşkil eden noktaların öğrenilmesi sağlanır (Akkaya, 2019).

"Bütünü oluşturan parçaları isimlendirir" kazanımı SOEP’te bulunurken TOEP’te bulunmamaktadır. Bu kazanım parça-bütün ilişkisini ifade etmektedir. Fakat TOEP’te bulunan "Parça bütün ilişkisini kavrar" kazanımın içeriğinden farklıdır. Örneğin 5 tane elmanın 2 elma ve 3 elma veya 1 elma ve 4 elmadan oluşabileceği anlamındadır. SOEP'te bu kazanımın toplama ve çıkarma işlemlerine zemin hazırladığı belirtilmektedir. Bir çokluğu onun parçaları cinsinden düşünmeye yoğunlaşmanın, sayı hissinin gelişmesi için önemli (Van de Walle, Karpve Bay-Williams, 2016) olduğu düşünüldüğünde bu kazanımın bulunması önemlidir. Resnick (1993) okulun ilk yıllarındaki en önemli kavramsal başarının sayının onu oluşturan parçalar cinsinden yorumlanması olduğunu ve sayı hissinin geliştirilmesinin küçük çocukların o ana kadar sahip olmadıkları yorumun ve matematiksel problem çözmenin farklı biçimlerini ele almayı mümkün kılacağını belirtmiştir. Bu bağlamda bu kazanımın okul öncesi dönemde verilmesinin gerekli olduğu düşünülebilir.

TOEP’te nesneleri kullanarak basit toplama ve çıkarma işlemlerini yapmaya ilişkin kazanım bulunurken SOEP'te bulunmamaktadır. Fakat SOEP’te bulunan “Bütünü oluşturan parçaları isimlendirir" kazanımının etkinlikleri arttırma ve eksiltme işlemi üzerine kurulmuş sorulardan oluşmaktadır. Çocuklarda matematiksel düşünme süreci sıralama aşaması, gelişmiş aşama ve parçabütün aşamalarından oluşur. Çocuk sıralama aşamasında toplama işlemi için üzerine ekleme, çıkarma işlemi içinbütünü eksiltme yolunu kullanabilir. Gelişmiş aşamada, çocuk çıkarma işlemini geriye doğru sayarak yapar. Parça-bütün aşamasında, çocuk çıkarmayı toplamanın tersi olarak görür, ileriye veya geriye doğru sayarak problemi çözer (Erdoğan ve Baran, 2005; Wright, 1992). Bu 
yönüyle bakıldığında, SOEP’te verilen ilgili kazanımın daha üstbilişsel bir seviyede olduğu söylenebilir.

\section{Günlük Deneyimlerdeki Temel Şekilleri ve Temel Mekânsal Kavramları Tanıma ve Kullanma}

Okul öncesi eğitiminde geometri içeriğinde şekiller dört temel kategoride tanımlanmaktadır: daire, kare, üçgen ve dikdörtgen (Clements, 1998, MEB, 2013, MOE, 2013). SOEP’te temel geometrik şekillerin farklı boyutları ve farklı pozisyonları verilirken TOEP’te verilmemektedir. Geometrik şekillerin farklı boyutları ve farklı pozisyonlarının verilmesi çocuklarda erken matematik becerileri olan sıralama, sınıflandırma ve karşılaştırma becerilerinin gelişmesine katkı sağlayabilir (Hannibal ve Clements, 2000). Yapılan bu araştırmalar aynı zamanda, bu tür başarısızlıkların sebebinin geometrik şekillerin öğretiminde çoğunlukla tipik örneklere yer verilmesi olduğunu göstermektedir ki okul öncesi dönemindeki çocuklara geometrik şekiller öğretilirken, şekillerin tipik olmayan örneklerinin de sunulması gerektiğini ortaya koymaktadır (Sezer ve Güven, 2019). Çok çeşitli sayıda tipik ve tipik olmayanları çocuklara sunmak gerekir; çocuklar, üçgen ve dikdörtgen örneklerinin “uzun”, “dar” ve "geniş” örneklerini de içeren daha geniş şekil çeşitliliğini görmelidir (Clements, 1998). Bu bağlamda, TOEP’te de geometrik şekillerin farklı boyutları ve farklı pozisyonlarının verilmesi gerekmektedir. Eğer çocuklara çok çeşit içeren örnekler gösterilmezse, şekiller hakkında sinırlı bilgiye sahip olabilirler (Sarama ve Clements, 2006a).

SOEP’te diğer şekilleri oluşturmak için temel şekilleri kullanmaya ilişkin kazanım bulunurken TOEP'te bulunmamaktadır. Bu durum SOEP’te geometri öğretiminde öğrencilerden beklenen becerilerin açıkça ifade edildiğini göstermektedir. Çocukların şekilleri yeniden üretmesi ve şekil kombinasyonları oluşturması bakımından bu becerinin olması önemlidir. Şekiller ve şekil kombinasyonları hakkında bilgiler oluşturduktan sonra, çocuklar yeniden üretmeye teşvik edilmelidirler; şekilleri ürettikten sonra ise çocuklar yeni tasarımlar yapmaları için teşvik edilmelidirler (Sarama ve Clements, 2006b). Böylece çocuklar çevrelerindeki nesnelerin birden fazla geometrik şekli ile oluştuğunu fark edecektir.

Her iki programda da konumla ilgili uzay kavramı, mekân ve mekânın kullanımı ile kazanımlara yer verilmiştir. Mekan kavramı nesneler arasındaki mesafeyi, nesneler arası ilişkileri ve kişinin vücudunun yönünü içermektedir (Charlesworth, 2012). Bu kazanım Kesicioğlu ve Alisinanoğlu (2017) çalışmasında belirtiliği gibi uzaysal olarak düşünme, şekilleri farklı konumda görüntüleme ve hareketleri göz önünde canlandırma-çocukların matematiksel düşüncelerinin gelişmesi bakımından oldukça önemlidir (İvrendi, Erol ve Atan, 2018). Okul öncesi dönemdeki, basit haritalarla yapılan 
gözlemler, konum belirten sözcükler ve çeşitli konumlara göre yönlendirme kullanılarak yapılan etkinlikler çocukların uzaysal mantığının gelişmesinde önemli rol oynamaktadır (Copley, 2000).

SOEP' te “Konumu (üst/alt, ön/arka), yönü (yukarı/aşağ1, sol/sağ) ve mesafeyi (uzak/yakın) isimlendirir" şeklinde ifade edilerek kazanılması gerekilen beceriler ifade edilmiştir. TOEP’te ise yönergeye uygun olarak nesneyi doğru yere yerleştirme, harita ve krokiyi kullanma ve mekânda konum alma becerilerine ilişkin göstergeler bulunmaktadır. Uzay, altında, üstünde, içinde, dışında, en üstte, en altta, yukarıda, aşağıda, yanında, arasında, kenarında, uzak, yakın gibi sözcüklerle ifade edilir (Kesicioğlu ve Alisinanoğlu, 2017). Çocuklarda uzaysal kavramın gelişiminin çocukları aktif kılarak ve kendi deneyimleriyle gelişir (Piaget ve Inhelder, 2005). Bu kazanımların programlarda yer alması çocukları etkin kılma bakımından önemlidir.

\section{Ölçme Birimlerini Tanıma ve Kullanma}

SOEP’te "Nesne veya varlıkların özelliklerini karşılaştırır” kazanımı verilmiştir. TOEP’te ise "Nesneleri ölçer” kazanımı verilmiştir. TOEP’te bu kazanımın açıklamasında standart olmayan ölçme birimi olarak pipet, kalem, kürdan, silgi gibi malzemelerle parmak, karış, adım, ayak gibi doğal ölçme birimleri kullanılması gerektiği belirtilmiştir. Kazanım için verilen açıklamadan "Nesneleri ölçer” kazanımının sadece uzunluk ve ağırlık ölçme becerisi için verildiği anlaşılmaktadır. TOEP’te ölçme süreci, ölçme için kullanılacak olan standart olmayan birimlere dayanarak tahmin etme ile başlamaktadır, sonra bu standart olmayan birimle ölçüm yapılmaktadır. Daha sonra ise yapılan işlem için kullanılabilecek standart ölçme aracı gösterilmektedir. Ölçülerin tahmini ve sıklıkla kullanılan ölçü birimleri için kritik eşiklerin geliştirilmesi, öğrencilerin birimlere olan aşinalıklarına yardımcı olup hata yapmalarını önlemesi ve ölçmenin anlamlı kullanılmasına katkıda bulunması (Van de Walle, Karp ve Bay-Williams, 2016) bakımından TOEP’teki gibi ölçmenin tahminle başlaması önemlidir. Tahminde bulunma mantıksal düşünmeyi içermesi bakımdan ölçme sonucunu tahmin etme becerisinin programlarda yer almasının gerekli olduğu düşünülmektedir.

Matematik eğitimi bağlamında ölçme becerisine sahip öğrencilerin, aynı nitelikteki durum ya da nesneleri bir sayı ile ifade ederek kendi içerisinde karşılaştırması beklenir. Bu sayılar ağırlık, hacim, uzunluk, yükseklik gibi fiziksel özellikleri ve zaman, para, sıcaklık gibi fiziksel olmayan özellikleri ifade eder (Charlesworth, 2012). Hacribrahimoğlu (2017b) ölçme becerisini Piaget'nin gelişim dönemlerini temel alarak beş gelişim basamağı altında incelemiştir. İncelemesinde standart ölçme birimlerinin (metre, litre, kilogram, derece vb.) kullanılmasının soyut işlemler döneminin sonuna ve ilköğretim düzeyine denk geldiğini ifade etmektedir. TOEP’te standart ölçme araçlarının neler olduğunun öğretilmesi ile sınırlı kalınması bu duruma uygun bir örnek olarak değerlendirilebilir. 


\section{SONUÇ ve ÖNERİLER}

TOEP ve SOEP arasında matematik içeriği bakımından fazla bir fark olmadığ1 görülmektedir. Ancak SOEP'te çocukların sayı hissi ve sayı kavramını içselleştirebilmeleri için bunlarla ilgili kazanımlara fazlaca yer verildiği belirlenmiştir. Gelman ve Gallistel (1986) tarafindan ileri sürülen sayma ilkeleri (bire bir eşleme, sabit sıra, kardinal sayı, soyutlama ve sıranın önemsizliği ilkeleri) ile sayı korunumu kavramını içeren kazanımlar SOEP’te bulunurken TOEP’te sayı korunumu kavramı ile sıranın önemsizliği ilkesine yönelik kazanımlar bulunmamıştır. TOEP’teki bu eksiklerin giderilmesine yönelik revize çalışmaları yapılabilir.

SOEP'in düzgün bir dizgiyle ve alanlara göre ek kılavuz yayınlayarak kolayca anlaşılma ve uygulama sağlama potansiyeli olduğu görülmektedir. Ayrıca SOEP kendisini oluşturan teoriler ve prensipleri paylaşarak öğretmenlerin kolayca bu teoriler ve prensipler üzerine araştırma yapmalarını sağlayacak şekilde hazırlanmıştır. Singapur, okul öncesi öğretmenleri için internet üzerinde kurduğu platform ile öğretmenlerin iletişimde olmasını sağlayarak etkinlik paylaşımı yapmalarını da sağlamaktadır. Bu ise SOEP' ve uygulama biçimimin daha profesyonel olduğu izlenimi vermektedir. Buna karşıllk Türkiye'de milli eğitim bakanlığı tarafindan internet üzerinde oluşturulan okul öncesi etkinlik havuzu ile MEB'in hazırladığı etkinliklere ulaşabilmesi önemli bir gelişmedir. Ancak bu çalışmaların daha da ilerletilmesinin gerekir.

$\mathrm{Bu}$ çalışma sadece Türkiye ve Singapur okul öncesi matematik eğitim programlarının içerik açısından karşılaştırılmasını içermektedir. İleriki çalışmalarda karşılaştırılan ülkelerin sayısı artırılarak, o ülkeler arasında program karşılaştırmaları yapılabilir ve böylece Türkiye okul öncesi programı matematik içeriği daha nitelikli hale gelmesi için ipuçları yakalanabilir. Çalışma kapsamında matematiğin temelini oluşturan sayıların öğretimi için TOEP’te kazanım sayısı artırılabilir ve sayılar içeriği tekrar gözden geçirilebilir. Aynıca TOEP’in öğretmenler tarafindan kolayca anlaşılabilmesi için dizgisinin yeniden düzenlenmesi gerekmektedir. SOEP’te öğrenme alanlarına göre kılavuzlar oluşturulduğu gibi TOEP’te de oluşturulabilir. Yaş düzeylerine göre farklı programların yapılması yararlı olacaktır.

\section{KAYNAKÇA}

Akçay, İ. (2006). Farkh Ülkelerde Okul Öncesi Öğrencilere Yönelike Çevre Eğitimi. (Yayınlanmış Yüksek Lisans Tezi). Bursa Uludağ Üniversitesi Sosyal Bilimler Enstitüsü. Bursa.

Akkan, Y., \& Çakıroğlu, Ü. (2012). Doğrusal ve ikinci dereceden örüntüleri genelleştirme stratejileri: 6-8. Sınıf Öğrencilerinin Karşılaştırılması. Eğitim ve Bilim(165), 104-120. 
Akkaya, R. (2019). Say1lar, Sayma ve Sayı Kavramı. İçinde (Editör: B. Durmaz) Erken Cocukllukta Matematik Eğitimi (s. 145-164). Ankara: Pegem Akademi Yayınları.

Akman, B. (2002). Okulöncesi dönemde matematik. Hacettepe Üniversitesi Eğitim Fakültesi Dergisi, 23, 244-248.

Alcock, L., \& Simpson, A. (2017). Interactions between defining, explaining and classifying: The case of increasing and decreasing sequences. Educational Studies in Mathematics, 94(1), 5-19.

Arnas, Y. A., \& Aslan, D. (2004). Okul öncesi dönemde geometri. Eğitim Bilim Toplum, 3(9), 36-45.

Baker, L., Mackler, K., Sonnenschein, S., \&Serpell, R. (2001). Parents' interactions with their firstgrade children during storybook reading and relations with subsequent home reading activity and reading achievement. Journal of School Psychology, 39(5), 415-438.

Baroody, J. A. (2004). The developmental bases for early chilhood number and operations standards. In D. H. Clements \& J. Sarama (Eds.) Engaging Young Children in Mathematics. Mahway, NJ: Lawrance Erlbaun Associates, Publishers.

Bozkurt, A., Çırak Kurt, S., \& Tezcan, Ş. (2020). Türkiye ve Singapur ortaokul matematik öğretim programlarının cebir öğrenme alanı bağlamında karşılaştırılması. Pamukkale Üniversitesi Eğitim Fakültesi Dergisi, 48, 152-173. doi: 10.9779/pauefd.540142

Charlesworth, R. (2012). Experiences In Math For Young Children. Sixth edition.Wadsworh: Cengage Learning.

Charlesworth, R., \& Lind, K. K. (2003). Math and science for young children. Fourth edition. Clifton Park, NY: Delmar/ITP

Clements, D. H. (1998). Geometric and Spatial Thinking in Young Children. Arlington, VA: National Science Foundation.

Copley, J. V. (2000). The young child and mathematics. Washington, DC: National Association for the Education of Young Children.

Cragg, L., \& Gilmore, C. (2014). Skills underlying mathematics: The role of executive function in the development of mathematics proficiency. Trends in neuroscience and education, 3(2), 63-68.

Creswell, J. W. (2007). Qualitative Inquiry and Research Design: Choosing Among Five Approaches (2. b.). California: Sage Publications.

Dewey, D., \& Tupper, D.E. (Eds.). (2004). Developmental motor disorders: A neuropsychological perspective. New York: The Guilford Press.

Dilek, H. (2016). T. C. MEB 2013 okul öncesi eğitim programı ile 2006 programının karşılaştırılması. İçinde (Editörler: Ö. Demirel \& S. Dinçer) Eğitim bilimlerinde yenilikler ve nitelik arayısı (s. 585-604). Ankara: Pegem Akademi.

Elliott, S., Carr, V., Arlemalm-Hagser, E., \& Park, E. (2017). Examining curriculum policy and pedagogy across borders: re-imagining socially transformative learning in early childhood education. In P. BlazeCorcoran, J. Weakland, \& A. Wals (Eds.), Envisioning futures for environmental and sustainability education (pp. 319-341). Wageningen: Wageningen Academic Publishers.

Erbilgin, E., \& Boz, B. (2013). Matematik öğretmeni yetiştirme programlarımızın Finlandiya, Japonya ve Singapur programları ile karşılaştırması. Hacettepe Üniversitesi Eğitim Fakültesi Dergisi, Özel, (1), 156-170.

Erdoğan, S. (2017). Okul öncesi dönemde matematik programı, İçinde (Editör: B. Akman) Okul Öncesi Matematik Eğitimi, 7. Baskı, Ankara: Pegem Akademi Yayınları. 
Erdoğan, S. Ç.,\& Baran, G. (2005). Erken çocukluk döneminde matematik. Eğitim ve Bilim, 28(130), $32-40$.

Ersan, C., \& İvrendi, A. (2016, Nisan). Okul öncesi dönem çocukları için geliştirilen araştırma temelli matematik eğitim programlarının incelenmesi. Ahi Evran Üniversitesi Kurşehir Eğitim Fakültesi Dergisi, 17(1), 39-56.

Gelman, R., \& Gallistel, C. R. (1986). The child's understanding of number. Harvard University Press.

Gerde, H. K., Wright, T. S., \& Bingham, G. E. (2019). Preschool teachers' beliefs about and instruction for writing. Journal of Early Childhood Teacher Education, 40(4), 326-351.

Griffin, S. (2004). Building number sense with number worlds: A mathematics program for young children. Early Chilhood Research Quarterly. 19(1), 173-180.

Haciibrahimoğlu, B. Y. (2017a). Örüntü ve fonksiyon. İçinde (Editör: B. Akman) Okul Öncesi Matematik Eğitimi (s. 122-130). Ankara: Pegem Akademi.

Haciibrahimoğlu, B. Y. (2017b). Ölçme. İçinde (Editörler: B. Akman, F. Alisinanoğlu, G. Baydemir, ve M. Buldu) Okul Öncesi Matematik. Eğitimi (s. 144-157). Ankara: Pegem Akademi.

Hannibal, M. A. Z., \& Clements, D. H. (2000). Young children's understanding of basic geometric shapes, Arlington, VA: National Science Foundation. grant no. ESI-8954644.

Incikabı, L., \& Tuna, A. (2012). Türkiye ve Amerika eğitim sistemlerinin 60-72 aylıklar için geliştirilen okul öncesi matematik eğitimi programı açısından karşılaştırılması. Mersin Üniversitesi Eğitim Fakültesi Dergisi, 8(3), 94-101.

İvrendi, A., Erol, A., \& Atan, A. (2018). A. 5-6 yaş çocuklarına yönelik geometri ve uzaysal alg1 testinin geliştirilmesi. Kastamonu Ë̆itim Dergisi, 26(6), 1823-1833.

Kabaran, G. G., \& Görgen, I. (2016). Güney Kore, Hong Kong, Singapur ve Türkiye'deki öğretmen yetiştirme sistemlerinin karşlaştırmalı olarak incelenmesi. Bartın Üniversitesi Eğitim Fakeültesi Dergisi, 5(2), 478-495.

Kandel, IL (1955). The study of comparative education. The Educational Forum, 20(1), 5-15.

Kesicioğlu, O. S., \& Alisinanoğlu, F. (2017). Okul öncesi dönemde uzay, geometri ve geometrik şekiller. İçinde (Editör: B. Akman) Okul Öncesi Matematik Eğitimi (s. 104- 119). Ankara: Pegem Akademi.

Krajcik, J. (2011). Learning progressions provide road maps for the development and validity of assessments and curriculum materials. Measurement: Interdisciplinary research and perspective, 9(23), 155-158.

Kul, Ü., \& Aksu, Z. (2016). Türkiye, Singapur, Güney Kore matematik öğretim programlarının pedagojik alan bilgisi bileşenleri bağlamında karşılaştırılması. Eræ̧incan Üniversitesi Eğitim Fakültesi Dergisi, 18(2), 900-921.

Le Corre, M., \& Carrey, S. (2007). One, two, three, four, nothing more: An insetigation of the conceptual sources of the verbal counting principles, Cognition,105, 395-438.

Levent, F., ve Yazıcı, E. (2014, Ocak). Singapur Eğitim Sisteminin Başarısına Etki Eden Faktörlerin İncelenmesi. Ë̈itim Bilimleri Dergisi, 39, 121-143.

Linder, S. M., Powers-Costello, B., \& Stegelin, D. A. (2011). Mathematics in early childhood: Research-based rationale and practical strategies. Early Childhood Education Journal, 39(1), 2937.

Marginson, S. (2011). Higher education in East Asia and Singapore: Rise of the Confucian model. Higher education, 61(5), 587-611. 
Marshall, C., \& Rossman, G. B. (1995). Designing qualitative research. Second Edition, London: Sage Publications.

MEB. (2013). T.C Milli Ë̆itim Bakanlĭğ Temel Eğitim Genel Müdürlü̈̆̈̈. 12.11.2018 tarihinde Temel Eğitim Genel Müdürlüğü: https://tegm.meb.gov.tr/dosya/okuloncesi/ooprogram.pdf adresinden erişilmiştir.

Miles, M. B., Huberman, A. M., Huberman, M. A., \& Huberman, M. (1994). Qualitative data analysis: An expanded sourcebook. California: Sage publications.

MOE. (2013). A Curriculum Framework. for Kindergartens in Singapore Numeracy Guide. Singapore: MOE.

MOE. (2018). 06.11.2019 tarihinde https://www.moe.gov.sg/microsites/moekindergarten/ faq.html adresinden erişilmiştir.

Mueller, J. J., \& File, N. (Eds.). (2019). Curriculum in Early Childhood Education: Re-examined, Reclaimed, Renewed. New York: Routledge.

Nesin, A. (2017). Kümeler Kuramı 1. İstanbul: Nesin Yayınc1lık.

Olkun, S., \& Uçar, Z. T. (2012). İlköğretimde Etkinlik Temelli Matematik Öğretimi. Ankara: Eğiten Kitap.

Olkun, S., Fidan, E., \& Özer, A. B. (2013). 5-7 yaş aralı̆̆ındaki çocuklarda sayı kavramının gelişimi ve saymanın problem çözmede kullanımı. Ë̆titim ve Bilim, 38(169), 236-248.

Piaget, J., \& Inhelder, B. (2005). The Child's Conception of Space. New York: London and New York.

Polonsky, L., Freedman, D., Lesher, S. \& Morrison, K. (1995). Math for the very young: a handbook of activities for parents and teachers, Chicago: John Wiley \& Sons Inc.

Postlethwaite, T. N. (1988). Preface. In T. N. Postlethwaite (Ed.), The encyclopedia of comparative education and national systems of education (s. 17-21). Oxford: Pergamon.

Resnick, M. (1993). Behavior Construction Kits. Communications. ACM 36, 7: 64-71.

Sarama, J., \& Clements, D. H. (2006a). Early Math: Introducing Geometry to Young Children. Early Childhood Today. 20(7), 12-13.

Sarama, J., \& Clements, D. H. (2006b). Mathematics in kindergarten. YC Young Children, 61(5), 3841.

Sezer ve Güven (2019). 5-7 yaş grubu çocukların geometri becerilerinin incelenmesi. Erken Çocukluk Çalssmalar Dergisi, 3(2), 514-540.

Taşkın, N. (2017). Küçük Çocuklarda Say1 Kavramı. İçinde (Editör: B. Akman) Okul Öncesi Matematik Eğitimi (s. 68-89). Ankara: Pegem Akademi.

Teo, T. W., Yan, Y. K., \& Ong, W. L. M. (2017). An investigation of Singapore preschool children's emerging concepts of floating and sinking. Pedagogies: An International Journal, 12(4), 325-339.

Uyanık, Ö., \& Kandır, A. (2010). Okul Öncesi Dönemde Erken Akademik Beceriler. Kuramsal Ë̈itimbilim, 118-134.

Van de Walle, J. A., Karp, K., S., \& Bay-Williams, J. M. (2016). Elementary and middle school mathematics: Teaching developmentally (9th ed.). Boston: Pearson.

Veziroğlu, M. (2017). Okul Öncesi Dönemde Matematik ve Fen İlişkisi. İçinde (Editör: B. Akman) Okul Öncesi Matematik Eğitimi (s. 213 -233). Ankara: Pegem Akademi.

Wang, J., Elicker, J., McMullen, M., \& Mao, S. (2008). Chinese and American preschool teachers' beliefs about early childhood curriculum. Early Child Development and Care, 178(3), 227-249. 
Wright, B. (1992). Number topics in early childhood mathematics curricula: historical back ground, dilemmas, and possible solutions. Australian journal of education, 36(2), 125-142.

Yıldırım, A., \& Şimşek, H. (2006). Sosyal bilimlerde nitel araștırma yöntemleri. Ankara: Seçkin Yayınları.

\section{EK-1}

I Kazanım 4. Nesneleri sayar. (Göstergeleri: İleriye/geriye doğru birer birer ritmik sayar. Belirtilen sayı kadar I I nesneyi gösterir. Saydığı nesnelerin kaç tane olduğunu söyler. Sıra bildiren sayıyı söyler. 10'a kadar olan sayılar | I içerisinde bir sayıdan önce ve sonra gelen sayıyı söyler.)

I Açıklamaları: Çocuktan belli sayıdaki nesne grubunu dokunarak saydıktan sonra son söylediği sayının nesne grubunun toplam sayısını gösterdiğini fark etmesi beklenir. Örneğin; Bir tabakta 5 tane kurabiye varsa çocuktan I ilk önce bunları sayması, sonra "kaç tane" diye sorulduğunda 5 (beş) yanıtını vermesi beklenir. Nesne grubunda I I birinci, ikinci sıradaki nesnenin kaçıncı olduğunu söylemesi beklenir. Verilen sayıdan önce/sonra gelen sayının I I hangi sayı olduğunu söylemesi beklenir.

Resim 1. TOEP “Nesneleri sayar” kazanımının göstergeleri ve açılamaları

\section{EK-2}

\begin{tabular}{|c|c|}
\hline Anahtar bilgi / beceriler / planlar & $\begin{array}{l}\text { ocukların öğrenme ve gelişiminin neye benzediğine dair } \\
\text { rnekler }\end{array}$ \\
\hline 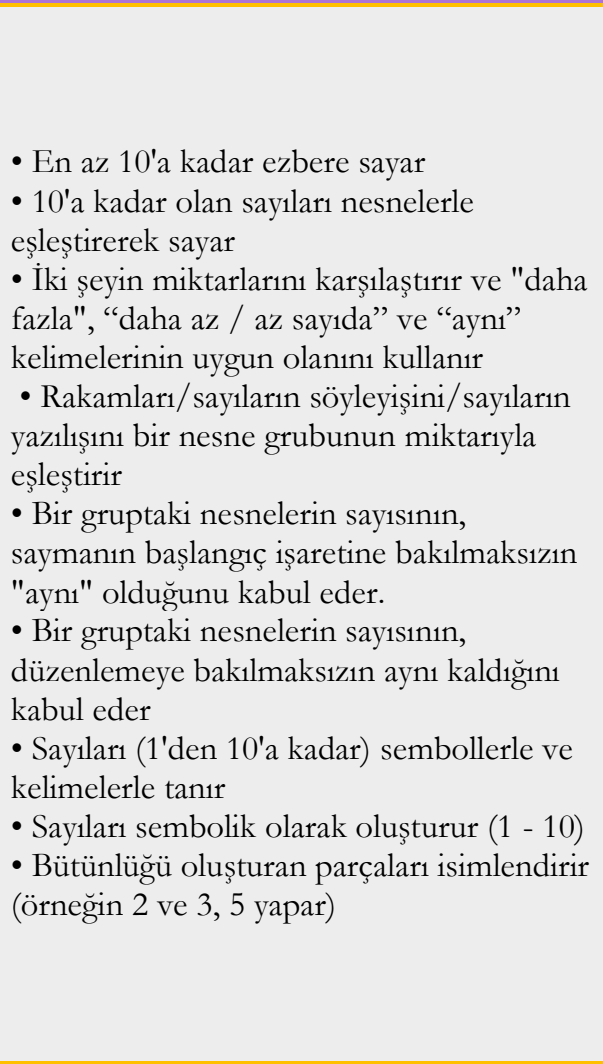 & $\begin{array}{l}\text { - Sayıları tekerlemeler veya şarkılarla doğru sırayla okur } \\
\text { - Bire bir eşleştirerek sayar (örneğin, bir nesneye dokunduğunda } \\
\text { sayıyı söyler) } \\
\text { - } 2 \text { grup nesneyi karşılaştırır ve } 1 \text { grubun diğerinden fazla olduğunu } \\
\text { fark eder } \\
\text { - } 2 \text { grup nesneyi karşılaştırmak için 'daha fazla' veya 'daha az' gibi bir } \\
\text { dil kullanır } \\
\text { - Bir grupta kaç nesne sorulduğunda kolayca sayım yapar } \\
\text { - Gerçek nesnelerin ve soyut şeylerin miktarını sayar ve bilir } \\
\text { (örneğin noktalar) } \\
\text { - Tombala veya domino gibi kart oyunlarında 2'li gruplarını eşleştirir } \\
\text { - Sayı miktarlarını çeşitli şekillerde temsil eder (örneğin nesneler, } \\
\text { parmaklar, 10luk bloklar, onluk çerçeve, çeltik kullanma) } \\
\text { - Çizgiler, sıralar, daireler veya rastgele düzenlemeler gibi farklı } \\
\text { düzenlemelerde sunulan nesnelerin sayılarını söyler } \\
\text { - Tabelalar, dergiler ve kitaplarda bildiği rakamları ve sayı } \\
\text { kelimelerini tanır ve söyler } \\
\text { - Sayıların isimlerini / sembollerini / sayı sözcüklerini bilir ve bir } \\
\text { gruptaki nesnelerin miktarlarıyla eşleştirir } \\
\text { - Düğme, fasulye ve hamur gibi malzemeleri kullanarak sayılar } \\
\text { oluşturur } \\
\text { - } 1 \text { ila } 10 \text { arasındaki sayıları yazar } \\
\text { - } 2 \text { nesnenin ve } 3 \text { nesnenin } 5 \text { nesnelik bir grup oluşturduğunu bilir } \\
\text { Not: Çocukların öğrenme ve gelişim örnekleri yaşa özgü ya da } \\
\text { ayrıntılı değildir. Öğretmenler, çocuklarının yeteneklerine, çıkarlarına } \\
\text { ve gelişim ihtiyaçlarına dayalı olarak uygun öğrenme fırsatları sunma } \\
\text { esnekliğine sahiptir. }\end{array}$ \\
\hline
\end{tabular}

\section{EK-3}

\begin{tabular}{|l|l|l|}
\hline $\begin{array}{l}\text { Anahtar } \\
\text { bilgi / } \\
\text { beceriler / } \\
\text { planlar }\end{array}$ & $\begin{array}{l}\text { Öğrenme } \\
\text { hedefleri }\end{array}$ & Etkinlikler \\
\hline $\begin{array}{l}10 ' a \text { kadar } \\
\text { olan sayıları } \\
\text { nesnelerle } \\
\text { eşleştirerek } \\
\text { sayar }\end{array}$ & $\begin{array}{l}\text { 5'e kadar olan } \\
\text { sayıları } \\
\text { nesnelerle } \\
\text { eşleştirerek } \\
\text { sayar }\end{array}$ & $\begin{array}{l}\text { Bir grupta } 5 \text { nesne sayın: } \\
\text { 5 sayma pulundan oluşan birkaç tabak hazırlayın. Çocuklardan sayma pullarını } \\
\text { bulundukları bir tabaktan boş bir tabağa tek tek sayarak almalarını isteyin. Bu, } \\
\text { sayılanların ve henüz sayılmamış olanların takip edilmesine yardımcı olur. }\end{array}$ \\
\hline
\end{tabular}




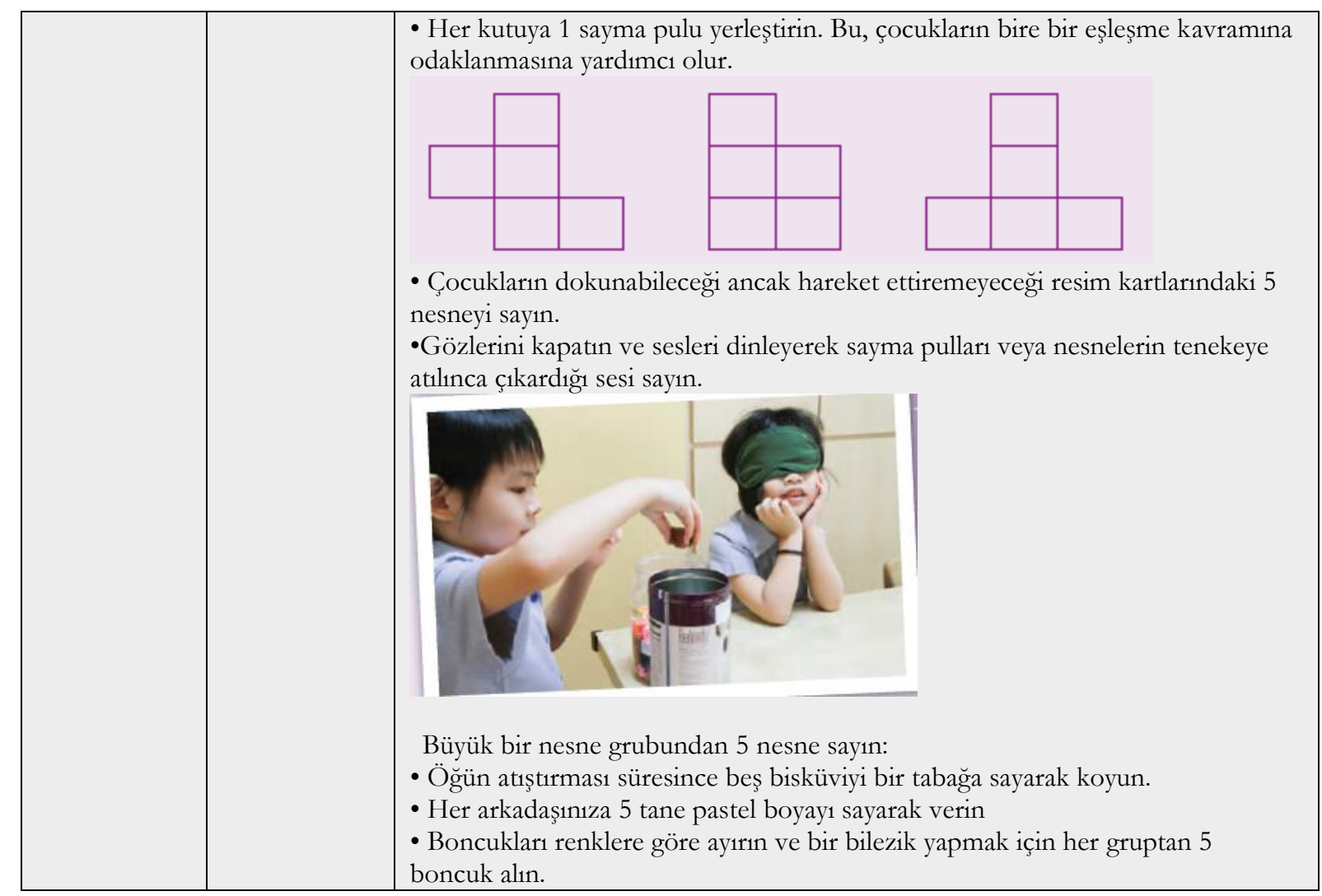

Resim 3. SOEP “10’a kadar eşlemeli sayım yapar” kazanımı ve açıklamaları 